\title{
KONSEP LEMBAGA PENJAMIN SIMPANAN \\ PADA KOPERASI INDONESIA
}

\author{
Agus Saiful Abib, B. Rini Heryanti, Dhian Indah Astanti
}

\author{
Fakultas Hukum Universitas Semarang \\ Jl. Soekarno-Hatta Tlogosari Semarang \\ E-mail: agus_saifulabib@yahoo.com
}

\begin{abstract}
Abstrack
Based on data from the Indonesia Ministry of Cooperatives and UMKM until 2015, the number of cooperatives in Indonesia reached 212.135 with the distribution of active cooperatives totaling 150,223 and inactive cooperatives reaching 61,912. These inactive cooperatives can have implications for members as creditors in the event of a bottleneck in the disbursement of funds belonging to cooperative members. This study aims to examine the arrangement of deposit insurance institutions in cooperatives as well as the concept of deposit insurance institutions in cooperatives. The results of this study state that the regulation of deposit insurance institutions in cooperatives is not specifically regulated in Law Number 25 of 1992 concerning Cooperatives. The establishment of a guarantor institution for cooperatives in Indonesia is a necessity to immediately establish a cooperative deposit guarantor institution by revising Law Number 25 of 1992 concerning Cooperatives by including the deposit guarantor institution in the cooperatives.
\end{abstract}

Key words: Deposit Insurance Agency, Cooperative, Indonesia.

\begin{abstract}
Abstrack
Berdasarkan data Kementerian Koperasi dan UMKM RI hingga tahun 2015 jumlah koperasi di Indonesia mencapai 212.135 dengan persebaran koperasi aktif berjumlah 150.223 dan koperasi tidak aktif mencapai 61.912. Koperasi tidak aktif tersebut dapat berimplikasi kepada anggota sebagai kreditur dalam hal terjadi kemacetan dalam pencairan dana milik anggota koperasi. Penelitian ini bertujuan mengkaji pengaturan lembaga penjamin simpanan pada koperasi serta konsep lembaga penjamin simpanan pada koperasi. Hasil penelitian ini menyatakan pengaturan lembaga penjamin simpanan pada koperasi tidak diatur secara spesifik dalam Undang-Undang Nomor 25 Tahun 1992 tentang Perkoperasian. Pembentukan lembaga penjamin pada koperasi di Indonesia adalah suatu keniscayaan untuk segera mungkin dibentuk lembaga penjamin simpanan koperasi dengan melakukan revisi terhadap Undang-Undang tentang Perkoperasian dengan memasukan lembaga penjamin simpanan pada koperasi.
\end{abstract}

Kata Kunci: Lembaga Penjamin Simpanan, Koperasi, Indonesia. 


\section{Latar Belakang}

Pada dasarnya sistem hukum adalah suatu kesatuan yang terdiri dari unsur-unsur yang mempunyai interaksi satu sama lain dan bekerjasama untuk mencapai tujuan kesatuan tersebut.' Lebih lanjut Satjipto Rahardjo menyatakan bahwa sistem hukum adalah suatu kesatuan yang bersifat kompleks yang terdiri dari bagian-bagian yang berhubungan satu sama lain. ${ }^{2}$ Oleh karena itu dalam kesatuan sistem hukum yang terdiri dari bagian-bagian hukum yang saling berkaitan harus saling menguatkan antara satu dengan yang lainnya guna mencapai tujuan hukum yaitu keadilan, kemanfaatan, serta ketertiban masyarakat. Koperasi dalam perekonomian Indonesia mempunyai kedudukan dan peran yang sangat strategis dalam pertumbuhan dan pengembangan potensi ekonomi rakyat. $^{3}$ Terjadinya berbagai permasalahan dalam koperasi khususnya penyelesaian perselisihan mengenai pengembalian dana milik anggota koperasi/kreditur merupakan keadaan yang kurang baik. Telah disadari bahwa koperasi adalah lembaga sosialekonomi yang memiliki peran penting dalam mendukung perkembangan kegiatan ekonomi kerakyatan, penanganan kemiskinan dan pengangguran. ${ }^{4}$ Oleh karena itu hukum harus mampu memberikan jawaban atas suatu keadan, sebagaimana yang disampaikan oleh Friedman yang membagi sistem hukum menjadi tiga komponen yaitu substansi hukum (legal substance) atau isi hukum yaitu peraturan-peraturan, struktur hukum (legal structure) yaitu sistem yudisial atau penegak hukum dan kultur (legal culture) atau budaya hukum yakni elemen sikap dan nilai sosial.

Perkembangan koperasi dimulai sejak jaman Hindia Belanda tepatnya di Purwokerto yang dimotori oleh E Siedeburgh sebagai kepala daerah Purwokerto dan penggantinya De Wolf van Westerrede yang mencatatkan diri sebagai perintis berdirinya koperasi pertama di Indonesia yaitu Purwokerto, sedangkan orang pribumi Indonesia yang mencatatkan dirinya sebagai perintis koperasi adalah Raden Aria Wiria Atmadja. ${ }^{5}$ Eksistensi koperasi di Indonesia mengalami progres yang cukup membanggakan, hingga tahun 2015 berdasarkan data dari Kementerian Koperasi dan UMKM Republik Indonesia, jumlah koperasi mencapai 212.135.

Menurut Pasal 1 angka (1) UndangUndang Nomor 25 Tahun 1992 tentang Perkoperasian yang dimaksud koperasi adalah badan usaha yang beranggotakan orang seseorang atau badan hukum koperasi dengan melandaskan kegiatannya berdasarkan prinsip koperasi sekaligus sebagai gerakan ekonomi

1 Sudikno Mertokusumo, Mengenal Hukum Suatu Pengantar, (Yogyakarta: Lyberti, 2019), Hlm 122.

2 Satjipto Rahardjo, Ilmu Hukum, (Bandung: Alumni, 2014), Hlm. 89.

3 Devi Agustia, Nunung Kusnadi, Harianto, "Studi Empiris Perilaku Usaha Koperasi: Kasus Koperasi di Dataran Tinggi Gayo Provinsi Aceh" Jurnal Manajemen \& Agribisnis Vol. 14 No. ,1 (Maret 2017): 12.

4 Tuti Budirahayu, "Perkembangan Koperasi di Jawa Timur" Dialektika Vol. 13 No. 1, (2018): 89

5 Mulhadi, Hukum Perusahaan Bentuk-Bentuk Badan Hukum di Indonesia, (Bogor: Ghalia Indonesia, 2017), Hlm. 117. 
rakyat yang berdasar atas asas kekeluargaan. International Labour Organitation (ILO) dalam resolusi nomor 127 tahun 1966 menjelaskan bahwa koperasi memiliki ciriciri utama sebagai berikut:

1. Koperasi merupakan kumpulan orangorang

2. Setiap anggota secara sukarela bergabung bersama

3. Anggota memiliki tujuan untuk mencapai tujuan ekonomi yang sama

4. Koperasi didirikan melalui pembentukan organisasi bisnis diawasi secara demokratis

5. Setiap anggota memberikan kontribusi modal yang sama dan menerima bagian risiko dan manfaat yang adil dari koperasi dimana anggota aktif berpartisipasi. ${ }^{6}$

Perkembangan koperasi di Indonesia saat ini mengalami pertumbuhan dan memiliki prospek perkembangan yang cukup menjanjikan, hal ini dapat terlihat dengan jumlah anggota koperasi hingga 31 Desember 2015 tercatat 37.783.160. Banyaknya koperasi dan anggota koperasi di Indonesia sebanding dengan banyaknya koperasi aktif sebanyak 150.223 dan koperasi tidak aktif sebanyak $61.192 .{ }^{7}$

Perkembangan koperasi mengindikasikan bahwa masyarakat Indonesia telah sadar dan mengerti betapa pentingnya koperasi dalam rangka mesejahterakan anggota pada khususnya dan masyarakat pada umumnya serta turut membangun pertumbuhan perekonomian nasional dalam rangka mewujudkan masyarakat adil makmur berlandaskan pancasila. Berdasarkan data Kementerian Koperasi dan UMKM RI sampai dengan 2015 anggota koperasi mencapai 37.873 .160 yang tersebar diseluruh Indonesia. Tingginya koperasi yang tidak aktif akan sebanding dengan kemungkinan ditutupnya koperasi dan berdampak terhadap anggota koperasi. Namun demikian, perkembangan jumlah unit Koperasi di Indonesia dari tahun ke tahun belum diimbangi dengan pertumbuhan kontribusi Koperasi terhadap perekonomian nasional Indonesia. ${ }^{8}$ Selama kurun waktu 3 (tiga) tahun terakhir yaitu 2015-2017 pemerintah telah melakukan penutupan koperasi sebanyak $40.013 .{ }^{9}$ Banyaknya koperasi yang ditutup pemerintah berimplikasi tehadap nasib anggota yang memiliki dana/kreditur, seringkali anggota koperasi nasibnya terkatung-katung lantaran dana yang dimiliki belum dikembalikan oleh koperasi yang dinyatakan tutup oleh pemerintah. Dalam Undang-Undang No. 25 Tahun 1992 tentang Perkoperasian yang terdiri dari 16 bab dan 67 pasal tidak menyebutkan

6 Rr. Dijan Widijowati, Hukum Dagang, (Jogjakarta: Andi Press, 2013), Hlm. 102.

7 http://www.depkop.go.id/pdfviewer/?p=uploads/tx_rtgfiles/1F_Koperasi_Desember_2015.pdf diakses tanggal 31 Agustus 2018

8 Hanny, dkk, “Analisis Reidentifikasi Empat Masalah Utama Koperasi di Kabupaten Subang sebagai Dasar Penyusunan Strategi”, Junal Akuntansi Vol.9, No. 1, (Mei 2017): 55

9 https://www.liputan6.com/bisnis/read/3131632/40013-koperasi-tutup-pada-3-tahun-pemerintahan-jokowi-jk diakses 3 September 2018 
keberadaan lembaga penjamin simpanan pada koperasi, hal ini berbeda dengan perbankan yang terdapat Lembaga Penjamin Simpanan (LPS) sebagaimana Undang-Undang RI Nomor 24 Tahun 2004 tentang Lembaga Penjamin Simpanan maupun Undang-Undang RI Nomor 1 Tahun 2013 Tentang Lembaga Keuangan Mikro.

Setiap koperasi menanggung beban untuk mengembalikan uang milik anggota koperasi akibat dari pembubaran, likuidasi maupun kepailitan. Hal ini merupakan beban dan tanggungjawab koperasi, oleh karena itu koperasi wajib melakukan tata kelola perusahaan yang baik (good corporate governance) guna mengantisipasi pengembalian dana kepada para anggota koperasi sekaligus menghindarkan dari terjadinya pencabutan ijin usaha dari pemerintah yang diwakili oleh Dinas Koperasi dan UMKM akibat pembubaran, likuidasi, kepailitan, maupun sebab lainnya yang dapat mengganggu tingkat kesehatan koperasi serta memberikan kepercayaan terhadap seluruh anggota koperasi.

Hingga saat ini terdapat banyak koperasi yang telah dicabut ijin usahanya oleh Dinas Koperasi dan UMKM. Pencabutan ijin usaha yang dilakukan oleh Dinas Koperasi dan UMKM membawa implikasi terhadap nasib anggota koperasi yang mengharapkan diberikannyajaminan pengembalian dana yang diterima dari koperasi. Untuk mengantisipasi hal demikian UU Perkoperasian telah menentukan bahwa untuk kepentingan kreditor dan para anggota koperasi terhadap pembubaran koperasi dilakukan penyelesaian pembubaran yang selanjutnya disebut penyelesaian. Tindak lanjut hal tersebut secara khusus diatur pada Pasal 54 UU No. 25 tahun 1992 tentang Perkoperasian yang menyatakan: “menggunakan sisa kekayaan koperasi untuk menyelesaikan sisa kewajiban koperasi." Hal ini tentunya sangat membantu bagi kreditor dan anggota koperasi ketika terjadi pencabutan ijin usaha, maka dana kreditor dan anggota koperasi akan dikembalikan sesuai dengan peraturan perundang-undangan.

Keberadan lembaga penjamin simpanan pada koperasi hingga saat ini belum terbentuk, meski beberapa pihak yang terkait telah merekomendasikan kepada pemerintah untuk membentuk lembaga penjamin simpanan pada koperasi. Sementara itu program penjaminan (protection investment fund) bagi perbankan telah dilaksanakan pada tahun 2004 oleh Lembaga Penjamin Simpanan dan Lembaga Penjamin Simpanan pada Lembaga Keuangan Mikro (LPS-LKM). Dalam melakukan penjaminan terhadap kreditor bank karena adanya kerugian akibat kesalahan perusahaan maka nasabah akan diberikan ganti rugi maksimal Rp. 2.000.000.000,00 (dua miliar rupiah). Tahun 2004 nasabah perbankan melalui UU No. 24 Tahun 2004 tentang Lembaga Penjamin Simpanan memberikan jaminan terhadap setiap nasabah perbankan sebesar Rp. 100.000.000,00 (seratus juta rupiah) yang kemudian direvisi pada tahun 2008 dimana besaran dana jaminan nasabah 
perbankan mengalami kenaikan hingga Rp. 2.000.000.000,00 (dua milyar rupiah). Simpanan pada lembaga keuangan mikro tidak disebutkan secara pasti besaran jaminan yang diberikan kepada setiap nasabah. Pasal 19 UU LKM hanya menegaskan bahwa untuk menjamin simpanan masyarakat pada LKM Pemerintah Daerah dan/atau LKM dapat membentuk lembaga penjamin simpanan LKM, serta dalam hal diperlukan, Pemerintah bersama Pemerintah Daerah dan LKM dapat mendirikan lembaga penjamin simpanan LKM. Berdasarkan latar belakang di atas penulis tertarik untuk melakukan penelitian dengan judul Konsep Lembaga Penjamin Simpanan Pada Koperasi Di Indonesia.

Berdasarkan uraian latar belakang yang dikemukakan di atas, maka penulis mengambil beberapa permasalahan yang sesuai dengan penulisan ini, yaitu:

1. Bagaimana pengaturan lembaga penjamin simpanan pada koperasi Indonesia?

2. Bagaimana konsep lembaga penjamin simpanan pada koperasi Indonesia di masa depan?

Secara garis besar, jenis penelitian hukum dapat dibagi menjadi dua katagori, yaitu jenis penelitian hukum normatif (yuridis normatif) dan penelitian hukum sosiologis (yuridis sosiologis). ${ }^{10}$ Dalam kaitannya dengan dua jenis penelitian hukum di atas, maka jenis penelitian yang digunakan adalah jenis penelitian yuridis normatif.

Penelitian konsep lembaga penjamin simpanan pada koperasi Indonesia ini merupakan penelitian hukum normatif dengan cara menginventarisasi beberapa aturan dalam hukum positif, asas-asas hukum, penemuan hukum in concreto dan sinkronisasi hukum.

Spesifikasi penelitian yang digunakan dalam penelitian ini adalah deskriptif analitis yaitu menggambarkan peraturan perundangundangan yang berlaku sebagai hukum positif dikaitkan dengan teori hukum dan praktek pelaksanaan hukum positif. Sebagai penelitian deskriptif analitis bertujuan menggambarkan secara tepat sifat-sifat suatu individu, keadaan, gejala atau kelompok tertentu atau untuk menentukan ada tidaknya hubungan antara suatu gejala dengan gejala lain dalam masyarakat. ${ }^{11}$

Bahan hukum yang diperoleh melalui studi kepustakaan untuk mendapatkan konsepsikonsepsi, teori-teori, pendapat-pendapat atau landasan teoritis yang berhubungan erat dengan permasalahan yang dibahas yang berupa bahan hukum primer, sekunder dan tersier.

10 Soerjono Soekanto membagi jenis penelitian hukum menjadi dua, yaitu penelitian hukum normatif (yuridis normatif) dan penelitian hukum sosiologis (yuridis sosiologis/empiris). Sedangkan Soetandyo Wignjosoebroto menggunakan istilah yang berbeda, yaitu penelitian hukum doktrinal dan penelitian hukum non doktrinal. Lihat Soerjono Soekanto, Pengantar Penelitian Hukum, (Jakarta: UI Perss, 2006), hlm 51, 52; Soetandyo Wignjosoebroto, Ragam-ragam Penelitian Hukum. Tulisan dalam Sulistyowati Irianto dan Shidarta (ed), Metodologi Penelitian Hukum Konstelasi dan Refleksi, (Jakarta: Yayasan Obor, 2011), hal 121; Lihat juga Barda Nawawi Arief, Penelitian Hukum Normatif (Suatu Upaya Reorientasi Pemahaman), dipaparkan dalam Penataran Metodologi Penelitian Hukum, Universitas Jendral Soedirman, Purwokerto, 11-15 September 1995, hal 3.

11 ibid, halaman 25. 
a. Bahan hukum primer meliputi;

1. Undang-Undang RI Nomor 25 Tahun 1992 tentang Perkoperasian;

2. Peraturan Presiden RI Nomor 12 Tahun 1967 tentang Pokok-Pokok Perkoperasian;

b. Bahan hukum sekunder

Buku teks hukum, jurnal hukum, pendapat para sarjana, komentar atas putusan hakim dan yurisprudensi.

c. Bahan hukum tersier

Bahan hukum yang memberikan petunjuk atau penjelasan atas bahan hukum primer dan sekunder berupa kamus, artikel, ensiklopedia.

Soerjono Soekanto mengemukakan, analisis dapat dirumuskan sebagai suatu proses penguraian secara sistematis dan konsisten terhadap gejala-gejala tertentu. ${ }^{12}$ Terdapat keterkaitan yang erat antara metode analisis data dengan pendekatan masalah yang digunakan. Data yang telah diperoleh selanjutnya dianalisis secara kualitatif.

\section{Pembahasan}

\section{A. Pengaturan Lembaga Penjamin Pada Koperasi Indonesia}

Hukum merupakan aturan yang terus berkembang menyesuaikan jaman dan tidak pernah berhenti untuk menciptakan suatu gagasan baru guna mewujudkan keadilan, kemanfaatan dan kepastian. Hukum harus mampu merespon setiap permasalahan dengan memberikan solusi atas segala hiruk pikuk problematika kehidupan bermasyarakat berbangsa dan bernegara. Perkembangan pola pikir manusia tentang konsepsi hukum berdampak terhadap perubahan hukum yang sangat fundamental sehingga hukum dapat membawa perubahan guna merealisasikan nilai-nilai keadilan. Sesungguhnya hukum tidak menabukan perubahan, tanpa perubahan, hukum akan ditinggalkan masyarakat, pada tataran yang konkrit maka perubahan terjadi pada sistem dan peraturan hukum. ${ }^{13}$

Saat ini hukum Indonesia dipandang sebagai aturan yang tidak baku dan tidak kaku, sehingga dimungkinkan hukum nasional masih dapat berubah sepanjang memenuhi syarat untuk mengikuti perkembangan jaman guna mencapai tujuan negara. Menurut Gustav Radbruch ${ }^{14}$ hukum harus memenuhi tiga nilai yaitu keadilan, kegunaan, dan kepastian hukum. Oleh karena itu perubahan hukum idealnya harus membawa implikasi positif dengan adanya nilai-nilai keadilan, kegunaan dan kepastian hukum guna memperkokoh pembangunan dan pembaharuan hukum nasional. Perubahan hukum tersebut merupakan respons terhadap permasalahan sosial masyarakat khususnya Lembaga Penjamin Simpanan pada Koperasi

12 Soerjono Soekanto sebagaimana dikutip Barda Nawawi Arief, Kebijakan Legislatif Dalam Penanggulangan Kejahatan dengan Pidana Penjara, (Yogyakarta: Genta Publisihing, 2010), hlm 68.

13 Sadjipto Rahardjo, Hukum Progresif Sebuah Sintesa Hukum Indonesia, (Yogyakarta: Genta Publishing, 2009), Hlm 59.

14 Gustav Radbruch dalam Satjipto Raharjo, Ilmu Hukum, (Jakarta: Citra Aditya Bakti, 2014), Hlm. 19. 
di Indonesia. Permasalahan dalam bidang koperasi khususnya mengenai Lembaga Penjamin Simpanan Kopersi (LPS Koperasi) hingga saat ini belum memperoleh hasil maksimal, sehingga dapat menimbulkan permasalahan hukum yang berlarut-larut. Keadaan yang demikian pada akhirnya merugikan masyarakat Indonesia, oleh karena itu harus segera ada pembangunan hukum dalam bidang perkoperasian.

Pembangunan secara sederhana berarti merubah suatu keadaan yang kurang baik menjadi lebih baik atau yang tidak ada menjadi ada. Demikian pula Lembaga Penjamin Koperasi (LPS Koperasi) hingga saat ini belum ada. Keadaan tersebut diakibatkan belum ditentukannya lembaga yang melakukan penjaminan atas seluruh dana milik kreditor dan anggota koperasi Indonesia ketika mengalami kepailitan maupun likuidasi. Scholten sebagaimana dikutip Sudikno Mertokusumo berpendapat bahwa hukum itu merupakan sistem terbuka karena berisi peraturan-peraturan hukum yang sifatnya tidak lengkap dan tidak mungkin lengkap. ${ }^{15}$ Oleh karena itu diperlukan adaya pembangunan hukum dengan membentuk hukum baru yang sesuai dengan nilai-nilai luhur bangsa Indonesia untuk melengkapi sistem hukum yang terbuka dan tidak lengkap.

Pengembangan usaha di koperasi diarahkan agar koperasi mampu mengembangkan prakarsa dan swakarsa. ${ }^{16}$
Koperasi menurut Pasal 1 angka (1) UU Perkoperasian menyatakan koperasi adalah badan usaha yang beranggotakan orang seorang atau badan hukum koperasi dengan melandaskan kegiatannya berdasarkan prinsip koperasi sekaligus sebagai gerakan ekonomi rakyat yang berdasar atas asas kekeluargaan.

Menurut Publikasi ILO (International Labour Organization) berjudul "Cooperative Administration and Management" 1960 koperasi didefinisikan sebagai:

"A Cooperative is association of persons usually of limited economic and through the formation of a democratically controlled busines organization, making equitable contribution to the capital required and accepting a fair share of the risks and benefits of the undertaking"

Terjemah bebasnya sebagai berikut: koperasi adalah suatu perkumpulan yang terdiri dari orang-orang umumnya yang ekonominya lemah yang secara sukarela mengabungkan diri untuk mencapai suatu tujuan bersama dalam bidang perkoperasian dengan jalan pembentukan perusahaan yang diawasi secara demokratis dimana masing-masing anggota secara ikhlas turut memberikan modal yang dibutuhkan dan masing-masing bersedia memikul risiko dan turut mengecap keuntungan-keuntungan yang timbul dari usaha itu menurut imbangan yang adil. ${ }^{17}$

15 Sudikno Mertokusumo, Mengenal Hukum Suatu Pengantar, (Yogyakarta: Liberty, 2019), Hlm. 124.

16 Candra Kurniawan, "Vera Desva Arianti, Analisis Kinerja Keuangan Koperasi Simpan Pinjam Wira Karya Lahat Kabupaten Lahat", Jurnal Neraca Vol. 2, No. 1, (Juni 2018) : 2

17 Sudarsono, Koperasi Dalam Teori dan Praktek, (Jakarta: Rineka Cipta, 2015), Hlm. 11. 
Moh Hatta bapak koperasi Indonesia, mendefinisikan koperasi sebagai usaha bersama untuk memperbaiki nasib penghidupan ekonomi berdasarkan prinsip saling tolong-menolong. ${ }^{18}$ Menurut peraturan koperasi negara Belanda tahun 1949 No. 179 terjemahan bebasnya sebagai berikut: "dengan perkumpulan-perkumpulan koperasi dalam peraturan ini dimaksudkan, perkumpulanperkumpulan orang-orang atau badan-badan hukum Indonesia yang memerdekakan masuk dan berhentinya orang-orang sebagai anggotanya dan berdasar atas persamaan, terutama bermaksud memajukan kepentingankepentingan jasmani para anggotanya dengan melakukan perdagangan atau pertukangan bersama-sama pembelian keperluankeperluannya tanggung menanggung kerugian dan jiwanya atau pemberian persekotpersekot atau pinjaman dan tentang pendirian perkumpulan-perkumpulan mana hrus dibuat surat akte (surat sah) yang didaftarkan atau diumumkan menurut cara yang diterangkan dalam peraturan ini. ${ }^{19}$

Koperasi sebagai gerakan ekonomi rakyat maupun sebagai badan usaha yang berperan serta untuk mewujudkan masyarakat yang maju adil dan makmur berlandaskan Pancasila dan Undang-Undang Dasar 1945. Setiap pembentukan koperasi didasarkan atas asas kekeluargaan dan demokrasi ekonomi. Hal ini bertujuan untuk menjadikan koperasi sebagai tonggak kemajuan perekonomian nasional sekaligus mesejahterakan anggota koperasi pada khususnya dan masyarakat pada umumnya serta ikut membangun tatanan perekonomian nasional. Pengaturan koperasi di Indonesia telah diatur melalui UndangUndang Nomor 25 Tahun 1992 tentang Perkoperasian. Koperasi adalah badan usaha yang beranggotakan orang seorang atau badan hukum koperasi dengan melandaskan kegiatannya berdasarkan prinsip koperasi sekaligus sebagai gerakan ekonomi rakyat yang berdasar asas kekeluargaan..$^{20}$

Perkembangan koperasi di Indonesia saat ini mengalami pertumbuhan dan memiliki prospek perkembangan yang cukup menjanjikan, hal ini dapat terlihat dengan jumlah anggota koperasi hingga 31 Desember 2015 tercatat 37.783.160. Banyaknya koperasi dan anggota koperasi di Indonesia sebanding dengan banyaknya koperasi aktif sebanyak 150.223 dan koperasi tidak aktif sebanyak 61.192..1 Dalam pembentukan koperasi disyarakatkan sekurang-kurangnya 20 (dua puluh) orang untuk pembentukan koperasi primer dan sekurang-kurangnya 3 (tiga) koperasi untuk pembentukan koperasi sekunder. Presiden RI dan Dewan Perwakilan

18 Ropi Marlina, Yola Yunisa Pratami, Koperasi Syariah Sebagai Solusi Penerapan Akad Syrkah yang Sah, Amwaluna, Vol. 1 No. 2 Juli 2017: 264

19 I Gusti Gede Raka, Pengantar Pengetahuan Koperasi, (Jakarta: Depdagkop, 1981), Hlm. 1-2.

20 Santi Kalefi, Penilaian Tingkat Kesehatan Koperasi Simpan Pinjam (KSP) Bantun Sejahtera Bantul 20122016, Jurnal Ekobis Nusantara Vol. 1, No. 6, (Juni 2018): 13

$21 \mathrm{http} / / /$ www.depkop.go.id/pdfviewer/?p=uploads/tx_rtgfiles/1F_Koperasi_Desember_2015.pdf diakses tanggal 31 Agustus 2018 
Rakyat (DPR) pada tahun 2012 pernah mengganti UU Perkoperasian tahun 1992 dengan Undang-Undang Nomor 17 Tahun 2012 tentang Perkoperasian saat kepemimpinan Presiden Susilo Bambang Yudhoyono dan membagi koperasi menjadi 4 (empat) jenis koperasi yaitu koperasi konsumen, koperasi produsen, koperasi jasa, dan koperasi simpan pinjam. Keberadaan Undang-Undang Nomor 17 Tahun 2012 tentang Perkoperasian telah dibatalkan dan dinyatakan tidak berlaku oleh Mahkamah Konstitusi (MK) melalui Putusan Nomor 28/PUU-XI/2013 karena dirasa muatan UU Perkoperasian 2012 sangat identik dengan korporasi dan telah menghilangkan asas kekeluargaan dan gotong royong sebagai ciri khas koperasi. Oleh karena itu untuk mengisi kekosongan hukum, maka MK memerintahkan untuk menggunakan UU Perkoperasian tahun 1992 hingga terbentuk UU Perkoperasian yang baru.

Keberadaan koperasi hingga saat ini banyaknya koperasi aktif sebanyak 150.223 dan koperasi tidak aktif sebanyak 61.192, sedangkan anggota koperasi mencapai 37.783.160, hal ini merupakan tantangan, kesempatan dan peluang dalam rangka mengembangkan koperasi hingga mampu menjadikan koperasi sebagai sarana dalam mesejahterakan anggota dan masyarakat serta ikut membangun tatanan perekonomian nasional. Koperasi dalam rangka mesejahterakan anggota dan masyarakat serta ikut membangun tatanan perekonomian nasional, maka koperasi harus melaksanakan koperasi dengan prinsip keanggotaan bersifat sukarela dan terbuka, pengelolaan dilakukan secara demokratis, pembagian sisa hasil usaha dilakukan secara adil dan sebanding dengan besarnya jasa usaha masing-masing anggota, pemberian balas jasa yang terbatas terhadap modal serta kemandirian. Dalam kegiatan koperasi tersebut juga memiliki fungsi dan peran sebagaimana diatur pada UU Perkoperasian yaitu:

a. membangun dan mengembangkan potensi dan kemampuan ekonomi anggota pada khususnya dan masyarakat pada umumnya untuk meningkatkan kesejahteraan ekonomi dan sosialnya;

b. berperan serta secara aktif dalam upaya mempertinggi kualitas kehidupan manusia dan masyarakat;

c. memperkokoh perekonomian rakyat sebagai dasar kekuatan dan ketahanan perekonomian nasional dengan Koperasi sebagai sokogurunya;

d. berusaha untuk mewujudkan dan mengembangkan perekonomian nasional yang merupakan usaha bersama berdasar atas asas kekeluargaan dan demokrasi ekonomi

Banyaknya anggota koperasi dan pembentukan yang selama ini dilakukan masyarakat baik koperasi primer dan koperasi sekunder, mengindikasikan bahwa masyarakat Indonesia telah sadar dan mengerti betapa pentingnya koperasi dalam rangka mesejahterakan anggota pada khususnya dan masyarakat pada umumnya serta turut 
membangun pertumbuhan perekonomian nasional dalam rangka mewujudkan masyarakat adil makmur berlandaskan Pancasila. Banyaknya koperasi yang didirikan oleh masyarakat seharusnya pemerintah harus melakukan pengasaan terhadap koperasi sehingga tata kelola yang dilakukan sesuai dengan standar yang diinginkan sekaligus meminimalisir koperasi yang bermasalah. Banyaknya koperasi di Indonesia juga sebanding dengan banyaknya koperasi yang dinyatakan tidak aktif bahkan ditutup oleh pemerintah, hal ini tentunya akan menjadi permasalahan bagi kreditur apabila koperasi tersebut dinyatakan ditutup.

Berdasarkan data Kementerian Koperasi dan UMKM RI sampai dengan 2015 anggota koperasi mencapai 37.873 .160 yang tersebar diseluruh Indonesia. Tingginya koperasi yang tidak aktif akan sebanding dengan kemungkinan ditutupnya koperasi dan berdampak terhadap anggota koperasi. Selama kurun waktu 3 (tiga) tahun terakhir yaitu 2015-2017 pemerintah telah melakukan penutupan koperasi sebanyak 40.013. ${ }^{22}$ Banyaknya koperasi yang ditutup pemerintah berimplikasi tehadap nasib anggota yang memiliki dana/kreditur, khususnya pada anggota koperasi simpan pinjam. Koperasi simpan pinjam adalah koperasi yang menjalankan kegiatan usaha simpan pinjam sebagai satu-satunya usaha yang melayani anggota. Koperasi simpan pinjam selayaknya bank yang melakukan penghimpunan dana masyarakat dan menyalurkannya kembali pada masyarakat dalam bentuk kredit. Terhadap pembubaran koperasi seringkali anggota koperasi nasibnya terkatung-katung lantaran dana yang dimiliki belum dikembalikan oleh koperasi yang dinyatakan tutup oleh pemerintah. Dalam Undang-Undang No. 25 Tahun 1992 tentang Perkoperasian yang terdiri dari 16 bab dan 67 pasal tidak menyebutkan keberadaan lembaga penjamin simpanan pada koperasi, hal ini berbeda dengan perbankan yang terdapat Lembaga Penjamin Simpanan (LPS) sebagaimana Undang-Undang RI Nomor 24 Tahun 2004 tentang Lembaga Penjamin Simpanan maupun UndangUndang RI Nomor 1 Tahun 2013 Tentang Lembaga Keuangan Mikro, serta Pasar Modal yang telah membentuk Securities Investor Protection Fund guna menjamin simpanan yang dimiliki investor pada pasar modal Indonesia.

Setiap koperasi menanggung beban untuk mengembalikan uang milik anggota koperasi akibat dari pembubaran, likuidasi maupun kepailitan. Hal ini merupakan beban dan tanggungjawab koperasi, oleh karena itu koperasi wajib melakukan tata kelola perusahaan yang baik (good corporate governance) guna mengantisipasi pengembalian dana kepada para anggota koperasi sekaligus menghindarkan dari terjadinya pencabutan ijin usaha dari 
pemerintah dalam hal ini diwakili oleh Dinas Koperasi dan UMKM akibat pembubaran, likuidasi, kepailitan, maupun sebab lainnya yang dapat mengganggu tingkat kesehatan koperasi serta memberikan kepercayaan terhadap seluruh anggota koperasi. Pengaturan tentang penjaminan terhadap dana milik anggota koperasi yang menjadi kreditur memang tidak diatur pada UU Perkoperasian akan tetapi kalau dibandingkan dengan UU No. 17 Tahun 2012 tentang perkoperasian yang telah dinyatakan tidak berlaku oleh Mahkamah Konstitusi, disana terdapat pasal yang mengatur tentang keberadaan Lembaga Penjamin Simpanan pada koperasi. Pasal 94 UU Nomor 17 Tahun 2012 menyakan bahwa koperasi simpan pinjam wajib menjamin simpanan anggota. Tindakan tersebut dilakukan dengan pemerintah dapat membentuk Lembaga Penjamin Simpanan Koperasi Simpan Pinjam untuk menjamin simpanan anggota. Hal ini sebagaimana tertuang dalam Pasal 94 ayat (2) UU No. 17 Tahun 2012 menyatakan Pemerintah dapat membentuk Lembaga Penjamin Simpanan Koperasi Simpan Pinjam untuk menjamin simpanan anggota sebagaimana dimaksud pada ayat (1). Lebih lanjut pada pasal 94 ayat (3) UU No. 17 Tahun 2012 menyatakan bahwa Lembaga Penjamin Koperasi Simpan Pinjam sebagaimana dimaksud pada ayat (2) menyelenggarakan program penjaminan Simpanan bagi Anggota Koperasi Simpan Pinjam. Berdasarkan hal tersebut Lembaga Penjamin Simpanan pada koperasi menurut penulis sangat baik dalam menjawab permasalahan hukum selama ini khususnya dalam bidang likuidasi/pembubaran koperasi yang mengakibatkan banyaknya anggota koperasi yang kehilangan simpanannya akibat ketiadaan lembaga penjamin simpanan pada koperasi. Akan tetapi UU Nomor 17 Tahun 2012 tentang Perkoperasian dibatalkan oleh MK sehingga perlindungan terhadap dana milik anggota koperasi belum memperoleh kepastian hinga sekarang.

Hingga saat ini terdapat banyak koperasi yang telah dicabut ijin usahanya oleh Dinas Koperasi dan UMKM. Pencabutan ijin usaha yang dilakukan oleh Dinas Koperasi dan UMKM membawa implikasi terhadap nasib anggota koperasi yang mengharapkan diberikannyajaminan pengembalian dana yang diterima dari koperasi. Untuk mengantisipasi hal demikian UU Perkoperasian telah menentukan bahwa untuk kepentingan kreditor dan para anggota koperasi terhadap pembubaran koperasi dilakukan penyelesaian pembubaran yang selanjutnya disebut penyelesaian. Tindak lanjut hal tersebut secara khusus diatur pada Pasal 54 UU No. 25 tahun 1992 tentang Perkoperasian menyatakan "menggunakan sisa kekayaan koperasi untuk menyelesaikan sisa kewajiban koperasi. Hal ini tentunya sangat membantu bagi kreditor dan anggota koperasi ketika terjadi pencabutan ijin usaha, maka dana kreditor dan anggota koperasi akan dikembalikan sesuai dengan peraturan perundang-undangan.

Pembubaran koperasi telah diatur pada 
Pasal 46-50 Undang-Undang Nomor 25 Tahun 1992 tentang Perkoperasian, dimana pembubaran koperasi dapat dilakukan berdasarkan keputusan rapat anggota dan keputusan pemerintah. Dalam hal pembubaran koperasi dilakukan pemerintah dilakukan apabila terdapat bukti bahwa koperasi yang bersangkutan tidak memenuhi ketentuan undang-undang koperasi, kegiatan koperasi bertentangan dengan ketertiban umum dan/ atau kesusilaan, kelangsungan usaha koperasi tidak dapat lagi diharapkan. Berdasarkan pertimbangan tersebut di atas pemerintah dan atas putusan rapat anggota dapat melakukan pembubaran koperasi yang akan berdampak terhadap kreditor, oleh karena itu setiap pembubaran koperasi baik berdasarkan keputusan rapat anggota maupun keutusan pemerintah wajib memberi tahukan kepada kreditor.

\section{B. Konsep Lembaga Penjamin Simpanan Pada Koperasi Indonesia}

Hukum adalah suatu institusi yang bertujuan mengantarkan manusia kepada kehidupan yang adil, sejahtera dan membuat manusia bahagia. ${ }^{23}$ Hukum nasional dibuat, dibangun dan dikembangkan guna menata kehidupan dan kemasyarakatan di seluruh Indonesia. Hukum nasional didayagunakan untuk merekayasa sendi-sendi kehidupan rakyat. ${ }^{24}$ Oleh karena itu pembangunan hukum adalah usaha terus menerus dilakukan guna melakukan perubahan dari suatu keadaan yang kurang baik menjadi lebih baik guna memberikan keadilan kesejahteraan dan kebahagiaan manusia. Hal ini terkait erat dengan seluruh aspek pembangunan hukum nasional khususnya lembaga penjamin simpanan koperasi. Hukum nasional itu sendiri adalah hukum atau peraturan perundangundangan yang dibentuk dan dilaksanakan untuk mencapai tujuan dasar dan cita hukum suatu negara. ${ }^{25}$ Dalam konteks ini maka pembentukan hukum nasional seharusnya berlandarkan pada Pancasila dan pembukaan UUD 1945 sebagai sumber hukum nasional. Oleh karena itu pembentukan peraturan perundang-undangan mengenai lembaga penjamin simpanan pada koperasi harus berdasarkan pancasila dan UUD 1945 sebagai cita dasar mewujudkan kesejahteraan bagi masyarakat Indonesia.

Setiap Hukum diposisikan sebagai alat untuk mencapai tujuan negara. ${ }^{26}$ Para pendiri bangsa dalam pembukaan UUD 1945 mengamanatkan untuk melindungi segenap bangsa Indonesia, dan seluruh tumpah darah Indonesia dan untuk memajukan kesejahteraan umum sebagai tujuan pembentukan negara. Oleh karena itu tidak ada salahnya apabila

23 Sadjipto Rahardjo, Hukum Progresif Sebuah Sintesa Hukum Indonesia, (Yogyakarta: Genta Publishing, 2009), Hlm. 2.

24 Soetandyo Wignjosoebroto, Hukum - Paradigma, Metode dan Dinamika Masalah, (Jakarta: Elsam dan Huma, 2003), Hlm. 173.

25 Moh. Mahfud MD, Membangun Politik Hukum Menegakkan Konstitusi, Jakarta, Rajawali Press, 2010, Hlm. 21.

26 Moh. Mahfud MD, Politik Hukum di Indonesia, (Jakarta: Rajawali Pers, 2010), Hlm. 2. 
penulis melakukan perbandingan hukum terhadap lembaga penjamin simpanan di beberapa undang-undang. Menurut Soenarjati Hartono sebagaimana dikutip $\mathrm{R}$ Soeroso menyatakan bahwa perbandingan hukum merupakan suatu metode penyelidikan dan bukan suatu cabang ilmu sebagaimana seringkali menjadi anggapan sementara orang. ${ }^{27}$ Sedangkan menurut $\mathrm{R}$ Soeroso sendiri bahwa perbandingan hukum adalah suatu cabang ilmu pengetahuan hukum yang menggunakan metode perbandingan dalam rangka mencari jawaban yang tepat atas problema hukum yang konkret. ${ }^{28}$

Jaminan keamanan dalam sistem keuangan menjadi suatu prioritas bagi negara guna memberikan keyakinan terhadap masyarakat terhadap dana yang dipercayakan pada koperasi. Keberadaan peraturan mengenai lembaga penjamin simpanan koperasi tentunya akan memberikan dampak baik terhadap stabilitas sistem keuangan serta memberikan rasa nyaman terhadap pemilik dana.

Keberadaan Lembaga Penjamin Simpanan (LPS) selama ini dikhususkan terhadap perbankan dan tidak dapat digunakan untuk melakukan penjaminan terhadap transaksi kegiatan yang lain. Pasal 1 angka 8 UndangUndang Nomor 24 Tahun 2004 tentang Lembaga Penjamin Simpanan menyatakan bahwa penjaminan adalah penjaminan yang dilaksanakan oleh lembaga penjamin simpanan atas simpanan nasabah bank. Pengaturan tersebut dilakukan untuk memberikan rasa aman bagi nasabah kreditur terhadap dana yang disimpannya di bank, sekaligus undangundang ini merupakan jawaban pemerintah dalam melakukan tindakan preventif dalam rangka menanggulangi penarikan massal yang dilakukan nasabah bank. Pembentukan LPS betujuan untuk menjamin simpanan nasabah penyimpan serta turut aktif dalam memelihara stabilitas sistem perbankan sesuai dengan kewenangannya.

Pembatasan UU LPS yang hanya diberlakukan kepada bank mengakibatkan ruang lingkup LPS hanya terkonsentrasi pada bank semata, padahal saat ini terdapat beberapa aturan tentang pembentukan lembaga penjamin simpanan pada kegiatan usaha non perbankan. Besaran simpanan yang dijamin oleh LPS mengalami perubahan dari Rp. 100.000.000,00 (seratus juta rupiah) sesuai Pasal 11 ayat (1) UU LPS menjadi Rp. 2.000.000.000,00 (dua milyar rupiah) sesuai Pasal 11 Perpu No. 3 Tahun 2008 tentang Perubahan atas Undang-Undang Nomor 24 Tahun 2004 Tentang Lembaga Penjamin Simpanan. Perubahan tersebut dilatar belakangi oleh krisis keuangan secara global yang dapat mempengaruhi stabilitas sistem keuangan nasional serta menjaga kepercayaan masyarakat terhadap perbankan. Perubahan besaran dana simpanan nasabah perbankan di Indonesia jika dibandingkan dengan negaranegara Asean termasuk yang tertingi dengan

27 R. Soeroso, Perbandingan Hukum Perdata, (Jakarta: Sinar Grafika, 2014), Hlm. 5.

28 Ibid, Hlm. 8. 
melewati Singapura dan Malaysia serta Thailand. Adapun besaran dana simpanan bank di Singapura adalah Rp. 500.00.000,00 (lima ratus juta rupiah), Malaysia Rp. 200.000.000,00 (dua ratus juta rupiah) dan Thailand

Saat ini UU Perkoperasian belum membentuk lembaga penjamin simpanan koperasi, sehingga terdapat kekhawatiran mengenai dana yang dimiliki kreditor dan anggota koperasi. Menurut Pasal 51 UU Perkoperasian telah menentukan bahwa untuk kepentingan kreditor dan para anggota koperasi terhadap pembubaran koperasi dilakukan penyelesaian pembubaran yang selanjutnya disebut penyelesaian. Selanjutnya Pasal 54 UU Perkoperasian menyatakan bahwa pihak penyelesaian akan menggunakan sisa kekayaan koperasi untuk menyelesaikan sisa kewajiban koperasi.

Pengertian penyelesaian di atas belum memberikan jaminan terhadap kreditor dan anggota koperasi atas segala risiko yang akan menimpa kreditor dan anggota koperasi akibat dari suatu keadaan yang tidak pasti yang dapat menimbulkan kerugian. Keberadaan UU Perkoperasian yang belum memberikan penggantian terhadap suatu keadaan yang tidak diharapkan di masa yang akan datang ternyata juga tidak terlepas dari risiko kepailitan, likuidasi dan pembubaran koperasi. Terjadinya pembubaran, likuidasi dan kepailitan koperasi menyebabkan terkatung-katungnya nasib kreditor dan anggota koperasi membuat pemerintah harus berfikir keras untuk memberikan perlindungan sekaligus jaminan akan pengembalian simpanan yang disetorkan nasabah koperasi dimana dinyatakan gagal bayar.

Lebih lanjut bahwa keberadaan Pasal 54 dan 55 UU Perkoperasian belum memberikan perlindungan dan rasa aman terhadap para kreditor dan para anggota koperasi apabila koperasi mengalami likuidasi maupun kepailitan, mengingat pasal tersebut menetapkan dan melaksanakan segala kewajiban pembayaran yang didahulukan dari pembayaran utang lainnya dan dalam hal terjadi pembubaran koperasi anggota hanya menanggung kerugian sebatas simpanan pokok simpnan wajib dan modal penyertaan yang dimilikinya.

Lebih lanjut diharapkan lembaga penjamin simpanan koperasi mampu menjembatani kebutuhan megenai persoalan atau permasalahan dalam bidang koperasi. Lembaga ini merupakan pilihan yang tepat dalam rangka menanggulangi permasalahan dalam bidang koperasi, sayangnya hingga sekarang lembaga penjamin simpanan koperasi belum dibentuk oleh pemerintah pasca pembatalan Undang-Undang Nomor 17 Tahun 2012 tentang Perkoperasian.

Dalam bidang pasar modal Untuk meningkatkan keamanan dalam berinvestasi di pasar modal Indonesia, maka setiap aset investor diberikan perlindungan dengan pembentukan Dana Perlindungan Pemodal oleh Indonesia Securities Investor Protection Fund (SIPF). Indonesia SIPF adalah perusahaan 
yang menyelenggarakan program Dana Perlindungan Pemodal, dan diawasi oleh Otoritas Jasa Keuangan (OJK).

Pemodal yang asetnya mendapat perlindungan Dana Perlindungan Pemodal adalah Pemodal yang memenuhi persyaratan sebagai berikut:

1. Menitipkan asetnya dan memiliki rekening Efek pada Kustodian

2. Dibukakan Sub Rekening Efek pada Lembaga Penyimpanan dan Penyelesaian oleh Kustodian dan

3. Memiliki nomor tunggal identitas pemodal (single investor identification) dari Lembaga Penyimpanan dan Penyelesaian.

Hal tersebut tidak berlaku bagi Pemodal yang memenuhi satu atau lebih kriteria berikut:

1. Pemodal yang terlibat atau menjadi penyebab Aset Pemodal hilang

2. Pemodal merupakan pemegang saham pengendali, direktur, komisaris, atau pejabat satu tingkat di bawah direktur Kustodian; dan/atau

3. Pemodal merupakan Afiliasi dari Pihakpihak tersebut pada angka 1 dan 2 .

Baik dalam segi aset yang dilindungi maupun dalam segi pemodal yang akan dilindungi, terdapat beberapa tahapan perlindungan yaitu dana perlindungan pemodal hanya memberikan ganti rugi kepada Pemodal yang merupakan nasabah Perantara Pedagang Efek yang mengadministrasikan rekening Efek nasabah dan Anggota Bursa Efek PT
Bursa Efek Indonesia. Terhadap Aset Pemodal, pemberian ganti rugi tersebut hanya terbatas pada Aset Pemodal berupa saham yang masuk dalam Penitipan Kolektif LPP dan dicatatkan pada BEI. Dana Perlindungan Pemodal hanya memberikan ganti rugi kepada Pemodal yang merupakan nasabah Perantara Pedagang Efek yang mengadministrasikan rekening Efek nasabah dan Anggota Bursa Efek PT Bursa Efek Indonesia dan yang merupakan nasabah Bank Kustodian. Terhadap Aset Pemodal, Dana Perlindungan Pemodal memberikan ganti rugi kepada Pemodal yang merupakan nasabah Bank Kustodian. Pemberian ganti rugi pada Aset Pemodal berupa dana yang mendapat perlindungan dana perlindungan pemodal adalah dana yang dititipkan pada Kustodian yang dibukakan Rekening Dana Nasabah pada Bank atas nama masing-masing Pemodal.

Penyelenggara dana perlindungan Pemodal melakukan kegiatan penanganan klaim Pemodal yang kehilangan aset pemodal setelah OJK menyatakan terdapat kondisi:

1. Terdapat kehilangan Aset Pemodal

2. Kustodian tidak memiliki kemampuan untuk mengembalikan Aset Pemodal yang hilang

3. Bagi Kustodian berupa Perantara PedagangEfekyangmengadministrasikan Efek dinyatakan tidak dapat melanjutkan kegiatan usahanya dan dipertimbangkan izin usahanya dicabut oleh OJK; atau

4. Bagi Bank Kustodian dinyatakan tidak dapat melanjutkan kegiatan usahanya sebagai Bank Kustodian dan 
dipertimbangkan persetujuan Bank

Umum sebagai Kustodian dicabut oleh OJK.

Dalam waktu paling lambat 3 (tiga) hari kerja setelah menerima penetapan dari OJK, Direksi Penyelenggara Dana Perlindungan Pemodal wajib:

1. Mengumumkan ke masyarakat melalui surat kabar/media lainnya jika terjadi peristiwa dimaksud di atas dan mengundang Pemodal terkait agar menyampaikan klaim kepada Penyelenggara Dana Perlindungan Pemodal dalam waktu tidak lebih dari 30 (tiga puluh) hari kerja sejak pengumuman dilakukan

2. Mengusulkan pembentukan komite klaim kepada OJK; dan

3. Membentuk tim verifikasi klaim.

Pembayaran ganti rugi kepada Pemodal dengan menggunakan Dana Perlindungan Pemodal dilakukan jika memenuhi ketentuan sebagai berikut:

1. OJK telah menerbitkan pernyataan tertulis bahwa:

a. Terdapat kehilangan Aset Pemodal

b. Kustodian tidakmemilikikemampuan untuk mengembalikan Aset Pemodal yang hilang; dan
c. Bagi Kustodian berupa Perantara Pedagang Efek yang mengadministrasikan Efek dinyatakan tidak dapat melanjutkan kegiatan usahanya dan dipertimbangkan izin usahanya dicabut oleh OJK; atau d. Bagi Bank Kustodian dinyatakan tidak dapat melanjutkan kegiatan usahanya sebagai Bank Kustodian dan dipertimbangkan persetujuan Bank Umum sebagai Kustodian dicabut oleh OJK.

2. Pemodal telah mengajukan permohonan ganti rugi kepada Penyelenggara Dana Perlindungan Pemodal sesuai dengan Peraturan OJK Nomor VI.A.5 tentang Penyelenggara Dana Perlindungan Pemodal

Ganti rugi sebagaimana dimaksud diberikan dalam bentuk dana sebesar nilai Aset Pemodal yang hilang dan/atau sesuai dengan batasan paling tinggi untuk setiap Pemodal dan setiap Kustodian yang ditetapkan oleh OJK. Ganti rugi atas nilai Aset Pemodal yang hilang tidak mencakup nilai kerugian atas perkiraan nilai investasi masa datang. Besaran ganti rugi aset pemodal adalah Rp 100 juta per Pemodal, dan Rp 50 miliar per Kustodian.

Lembaga penjamin simpanan juga terdapat pada lembaga keuangan mikro yaitu lembaga keuangan yang khusus didirikan untuk memberikan jasa pengembangan usaha dan pemberdayaan masyarakat, baik melalui pinjaman atau pembiayaan dalam skala usaha mikro kepada anggota dan masyarakat, pengelolaan simpanan, maupun pemberian jasa konsultasi pengembangan usaha yang tidak semata-mata mencari keuntungan.

Lembaga keuangan mikro dapat melakukan kegiatan usaha yaitu meliputi jasa pengembangan usaha dan pemberdayaan 
masyarakat, baik melalui Pinjaman atau Pembiayaan dalam usaha skala mikro kepada anggota dan masyarakat, pengelolaan Simpanan, maupun pemberian jasa konsultasi pengembangan usaha. Dalam melakukan kegiatan usaha lembaga keuangan mikro mengahadapai berbagai problematika atau permasalahan dikemudian hari. Hal tersebut dapat berdampak terhadap kepercayaan nasabah lembaga keuangan mikro dalam mempercayakan simpanannya. Oleh karena itu Untuk menjamin Simpanan masyarakat pada LKM, Pemerintah Daerah dan/atau LKM dapat membentuk lembaga penjamin simpanan LKM, Dalam hal diperlukan, Pemerintah bersama Pemerintah Daerah dan LKM dapat mendirikan lembaga penjamin simpanan LKM.

Dengan berbagai perbandingan sebagaimana di atas saat ini beberapa wacana pembentukan program penjamin koperasi ikut dalam kewenangan Lembaga Penjamin Simpnan (LPS). Padahal kita tahu bahwa saat ini LPS hanya memberikan jaminan terhadap dana nasabah yang disimpan diperbankan, baik Bank Umum (konvensional dan syariah) maupun Bank Perkreditan Rakyat (BPR). Oleh karena itu apabila program penjamin koperasi akan diberikan kewenangannya kepada LPS, maka harus ada revisi terhadap UndangUndang Nomor 24 Tahun 2004 tentang Lembaga Penjamin Simpanan. Alternatif yang berikutnya adalah dibentuk lembaga penjamin simpanan koperasi dengan melakukan revisi terhadap Undang-Undang Nomor 25 Tahun
1992 tentang Perkoperasian dalam rangka memberikan jaminan kepada kreditur sekaligus ikut serta dalam mesejahterakan anggota dan pembangunan ekonomi secara nasional

\section{Simpulan}

a. Pengaturan lembaga penjamin simpanan pada koperasi belum diatur pada undangundang Nomor 25 Tahun 1992 tentang Perkoperasian. Bab X Pasal 46 sampai dengan 50 tidak membahas secara spesifik tentang bentuk perlindungan bagi kreditur dalam rangka pembubaran koperasi.

b. Lembaga penjamin simpanan pada koperasi saat ini belum ada. Guna melindungi kreditur pada koperasi maka harus dibentuk lembaga penjamin simpanan pada koperasi dalam rangka memberikan rasa aman, nyaman dan tentram dalam rangka mesejahterkan anggota dan ikut serta dalam pembangunan ekonomi nasional melalui koperasi.

\section{Saran}

1. Pemerintah dan DPR wajib segera melakukan pembentukan Rancangan Undang-Undang Perkoperasian melalui program legislasi nasional dalam rangka mengganti Undang-Undang Nomor 25 Tahun 1992 tentang Perkoperasian guna memberikan kepastian hukum serta perlindungan terhadap kreditur ketika terjadi pembubaran koperasi 
2. Pemerintah bersama DPR wajib memasukan lembaga penjamin simpanan pada koperasi, sebagai solusi bagi permasalahan yang selama ini terjadi pada koperasi yang dilikuidasi dengan memberikan jaminan pengembalian dana sesuai dengan tingkat kewajaran guna memberikan perlindungan dan kepastian hukum sehingga mampu menjadikan koperasi sebagai sokoguru perekonomian bangsa.

\section{DAFTAR PUSTAKA}

\section{Buku}

Dijan Widijowati, Rr. Hukum Dagang, Jogjakarta: Andi Press, 2013.

Gede Raka, Gusti. Pengantar Pengetahuan Koperasi. Jakarta: Depdagkop, 1981. Ibrahim, Jhony. Teori dan Metodologi Penelitian Hukum Normatif. Surabaya: Bayumedia, 2019.

Mahfud MD, Moh. Membangun Politik Hukum Menegakkan Konstitusi. Jakarta: Rajawali Press, 2010. , Politik Hukum di

Indonesia, Jakarta: Rajawali Pers, 2010.

Mertokusumo, Sudikno. Mengenal Hukum

Suatu Pengantar, Jogjakarta: Liberty, 2019

Mulhadi. Hukum Perusahaan Bentuk-Bentuk Badan Hukum di Indonesia. Bogor: Ghalia Indonesia, 2017.

Rahardjo, Sadjipto. Hukum Progresif Sebuah

Sintesa Hukum Indonesia. Yogyakarta: Genta Publishing, 2009. Ilmu Hukum. Bandung:

Citra Aditya Bakti, 2014.
Soekanto, Soerjono dan Sri mamudji. Penelitian Hukum Normatif Suatu Tinjauan Singkat. Jakarta: Rajawali Press, 2015.

Soeroso, R. Perbandingan Hukum Perdata. Jakarta: Sinar Grafika, 2014.

Sudarsono. Koperasi Dalam Teori dan Praktek. Jakarta: Rineka Cipta, 2015.

Wignjosoebroto, Soetandyo. Hukum Paradigma, Metode dan Dinamika Masalah. Jakarta: Elsam dan Huma, 2003.

\section{Peraturan Perundang-undangan}

Sekretariat Negara RI. Undang-Undang Nomor 25 Tahun 1992 tentang Perkoperasian, Jakarta 1992.

Sekretariat Negara RI Peraturan Presiden Nomor 12 Tahun 1967 tentang PokokPokok Perkoperasian

\section{Jurnal}

Agustia, Devi dkk. "Studi Empiris Perilaku Usaha Koperasi: Kasus Koperasi di Dataran Tinggi Gayo Provinsi Aceh”. 
Jurnal Manajemen \& Agribisnis Vol. Marlina, Ropi dan Yola Yunisa Pratami. 14, No. 1, (Maret 2017) "Koperasi Syariah Sebagai Solusi

Budirahayu, Tuti. "Perkembangan Koperasi di Jawa Timur" . Dialektika Vol. 13, No. Penerapan Akad Syrkah yang Sah". 1, (2018)

Hanny, Kezia Kurniawati dkk. "Analisis

Reidentifikasi Empat Masalah Utama Koperasi di Kabupaten Subang sebagai

Dasar Penyusunan Strategi”. Junal Akuntansi Vol.9, No. 1, (Mei 2017) Amwaluna Vol. 1, No. 2, (Juli 2017)

\section{Website}

h t t p : / / w w w.d e p k o p.go.i d / pdfviewer/?p=uploads/tx_rtgfiles/1F_ Koperasi_Desember_2015.pdf diakses tanggal 31 Agustus 2018

Kurniawan, Candra dan Vera Desva Arianti. https://www.liputan6.com/bisnis/

"Analisis Kinerja Keuangan Koperasi $\mathrm{read} / 3131632 / 40013$-koperasi-tutupSimpan Pinjam Wira Karya Lahat pada-3-tahun-pemerintahan-jokowi-jk

Kabupaten Lahat", Jurnal Neraca Vol. diakses tanggal 3 September 2018

2, No. 1, (Juni 2018) 